\title{
Analysis of the Human Resources Policies RSU Royal Prima in the Face of the Pandemic of COVID-19
}

\author{
Sitti Afifa ${ }^{1}$, Ermi Girsang $^{2}$, Sri Wahyuni Nasution ${ }^{3}$, Chrismis Novalinda Ginting $^{4}$ \\ ${ }^{1}$ Postgraduate Students Department Magister of Public Health, Faculty of Medicines at University Prima \\ Indonesia \\ ${ }^{2,3,4}$ Postgraduate Lecturer Department Magister of Public Health, Faculty of Medicines at University Prima \\ Indonesia
}

Corresponding Author: Ermi Girsang [Email: ermigirsang@unprimdn.ac.id]

\section{ABSTRACT}

Currently there are as many as 65 countries infected with the corona virus. According to WHO as of March 2, 2020, the number of sufferers was 90,308 infected with Covid-19. The death rate reached 3,087 or $2.3 \%$ with a cure rate of 45,726 people. It is proven that the patient with the confirmation of Covid-19 in Indonesia originated from an event in Jakarta where the patient had contact with a Japanese national who lived in Malaysia. Hospitals will not be able to survive COVID-19 through hospital protocol and resources. Consider making passes. Second, use hospital personnel for the most relevant skills.

This study aims to determine the HR policy analysis of the Royal Prima Hospital in dealing with the COVID-19 Pandemic, using descriptive qualitative research with the method of collecting data using in-depth interviews (direct interviews) which are measured by data validity (triagulation) and using 5 samples is a related informant, then the data is processed and analyzed in tabular form which is described in narrative form.

The results of this study were found that in the input of the Royal Prima Medan General Hospital, the Policy on Health Protocols recommended by the government or WHO, found that the process of working and implementing policies as human resources has not been maximal in maintaining the distance between individual tablespoons, but the process of using APD is in accordance with the SOP. and meet Government or WHO standards. For
\end{abstract}

Output There is human resource data confirmed to be infected with the corona virus. The data consists of 6 medical personnel, namely 2 nurses and 4 doctors.

Keywords: COVID-19, Royal Hospital Human Resources Policy against Pandemic, Health Protocol.

\section{INTRODUCTION}

There are currently as many as 65 countries infected with the corona virus. According to the WHO as of the date of March 2, 2020 the number of patients with 90.308 infected with Covid-19.In Indonesia was until recently infected with 2 people. Mortality reached 3.087 or $2.3 \%$ with a cure rate 45.726 people. Proven patient is a confirmation of Covid-19 in Indonesia originated from an event in Jakarta where sufferers of contact with foreign nationals (foreigners) from Japan who lives in Malaysia. After meeting the patient complained of fever, cough, shortness of breath (WHO, 2020).

Novel Coronavirus (2019-nCoV) was later named as the disease COVID-19, began as an outbreak in the province of Wuhan in China, Before making his way around the world in a matter of months and become a pandemic.(Jacobson BH, 2020).

Because there is currently no vaccine for COVID-19, there is also no treatment dikomfirmasi, therefore, the best 
way to prevent and slow down transmission is to find out its causes and how it spreads. The WHO declared COVID-19 as an Emergency Public Health from Concern International (PHEIC) On January 30, 2020. This declaration means that the outbreak of the disease that involves more than one Country and therefore require a coordinated International response (Argenti PA, 2020).

When writing this paper, the latest data on the number of people affected by COVID-19 amounted to more than 4 million people with the number of deaths reaches 300,000 (Argenti PA, 2020)

Hospitals will not be able to survive COVID-19 through the protocols and resources of the hospital. The efforts of individual single consider making operSecond, use the power of the hospital to the skills that are most relevant. The role of the champion of the hospital, to doctors who become the frontline. This individual is a clinician pluripotent who feel comfortable with people who are high can lead in a specific area for example (APD, updates on patient acuity COVID-19 and can fit into a variety of positions clinical. Testing, protocol release) and act as a channel for the instinct of information early in the institutions, mobilize the doctors hospital in the entire country, and the resources (Yan w, 2020).

Meanwhile, the medical staff at most hospitals in the province of Hubei (especially Wuhan city) suffer from fatigue because the workload is very large and the lack of personal protection equipment, namely the supply of oxygen, a ventilator, an urgent need other is to immediately distinguish patients with covid-19 than the disease fever other. The development of new technologies is needed for the diagnosis of Covid-19, most of the laboratory testing based on the test nucleic acid of the virus. The hospital staffs have been trained to techniques to get the swipe of the nasopharynx with adequate quality. Therefore, samples for testing confirmation are no longer mandatory to be submitted to the $\mathrm{CDC}$, which helps to reduce the waiting time substantially (Pathogens of infection, 2020).

For the team of doctors who are on the front lines. This individual is a clinician pluripotent who feel comfortable with people who are high can lead in a specific area (for example, APD, updates on patient acuity COVID-19 and can fit into a variety of positions clinical. Testing, protocol release) and act as a channel to the instinct of the initial information to mobilize the doctors hospital in the entire country, updates, and resources. All areas with an increased need in the hospital (for example Filtering clinic - meetings and operational activities as it is time-consuming. (Yan w, 2020).

Pandemic Covid-19 is the event of large-scale disaster and stressful because it causes great damage, the difficulties and the death of many people in one or more social strata and a lot of things need adjustment in the individual and social level. Disasters such as Covid-19 also are social events such as physical, because it interferes with our daily routines, and it affects how we manage the social network (Bonanno, 2019)

Extraordinary events by the coronavirus are not the first time. 2002 (SARS) caused by SARS-coronavirus (SARS-CoV) and disease (MERS) in 2012, is due to the right ole MERS-CoV with a total accumulative cases around 10,000 (1000's of MERS cases and 8000 cases of SARS) mortality from SARS of about $10 \%$, while MERS is high which is about $40 \%$. (PDPI, 2020).

Judging from the situation of the spread of COVID-19 which is already almost out to all the provinces in Indonesia with the number of cases and number of deaths is increasing and the impact on aspects of the political, economic, social, cultural, defense and security, as well as the welfare of the people in Indonesia, the Indonesian Government has set the presidential decree No. 11 of the Year 2020 on the determination of emergency public health in Indonesia, The Indonesian government has settled presidential decree 

COVID-19.

No. 11 of the year 2020 on the determination of emergency public health corona virus disease 2019 (COVID-19) the Decision of the President set the COVID-19 as a type of disease that can cause emergency public health (KKM) and set KKM COVID-19 in Indonesia that must be done reduction efforts in accordance with the provisions of laws and regulations. In addition, upon consideration of the spread of COVID-19 Impact on the increase of the number of casualties and loss of property, of widespread coverage of the affected region, as well as the implications on the socioeconomic aspects which are widespread in Indonesia, has issued presidential decree No. 12 of the year 2020 on the determination of the disaster nonalam the spread of corona virus disease 2019 (COVID-19) As a National Disaster (Menkes 2020).

\section{LITERATURE REVIEW Hospital}

A hospital is a health care institution that organizes personal health services for panipurna that provides inpatient, outpatient, and emergency room (Moh, 2014).

\section{Hospital Services}

Outpatient services are medical Services to a patient and not more than 24 hours of service for the purpose of observation, diagnosis, treatment, rehabilitation, and other health services, without requiring such patients in inpatient care (Moh, 2010).

\section{Human Resources}

Human resources, the only resources that have the sense, the feeling, the desire, the ability, skills, knowledge, encouragement, resources and works, The only resources that have the ratio, taste and intention. All potential sources of human resources is very influential on the efforts of the organization in the achievement of the goal. No matter how advanced the technology, the development of the information, availability of capital and the inadequacy of the material, but if without human resources it will be difficult for the organization to achieve its goals. However the good formulation of the goals and plans of the organization, presumably only will be in vain, if the elements of human resources are not considered, especially if abandoned (Faustino CG, 1995).

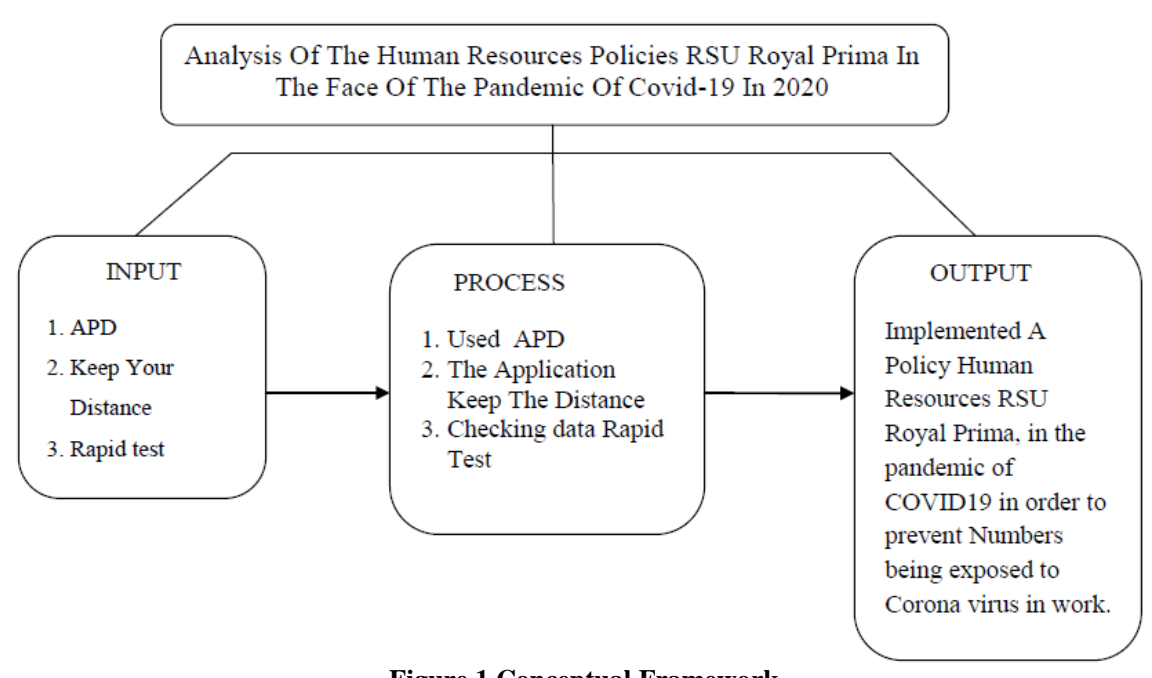

Figure 1 Conceptual Framework

\section{MATERIAL AND METHODS}

This research is a descriptive qualitative research. Where to get an overview of the in-depth information about the Human Resources policy of RS Royal
Prima in the face of the pandemic of COVID-19. With a look at the input (the Use of APD, Keep your Distance and Rapid test), the process consists of interviews with the informant, the output of the 
implementation process of a policy in accordance with the guidelines that have been set. By documenting the information obtained into the recording, and then translated into the transcript and then do the analysis, which are grouped into categories that match the topic are then compared with the opinions of experts. This research was conducted at RS Royal Prima Medan, which is located at Jl. Ayahanda No. 68 A, Sei Putih Tengah, Kec. Medan Petisah, Kota Medan, Sumatera Utara 20118. The time of Execution of Research is in the month of August 30 until september 30, 2020.

The subject of the research or the respondent are parties that serve as a sample in a study. The subjects in the research are informants who can provide information about the situation and conditions in the policy Analysis Human Resources RS Royal Prima in the face of pandemic (COVID-19) in the year 2020. The informant is a person who provides information about the situation and the condition of the background of the day. The informants of this study amounted to 5 people interviewed, comprising 1 director of medical services, 1 Nurse ER, 1 LAB Analyst, 1 doctor, 1 Cleaning Service, To the informant amounts to 1 person consists of Deputy director conducted through indepth interviews, document review, observation and are able to communicate well, be healthy, and willing to be informants of the study.

The type of Data used is Primary Data. The primary Data collected from the informants with the technique of in-depth interviews (depth interview) covering the Behavior Human Resources RS Royal Prima in the face of the pandemic corona virus (COVID19) and tips for keeping the welfare of the soul. Secondary Data; Secondary Data is obtained documents that are deemed necessary, among others, to obtain information Policy Human Resources RSU Royal Prima in the face of a pandemic COVID19.

Data Collection method is in-depth Interviews (depth interview) used to informants in the HR Policy RSU Royal Prima in the face of a pandemic COVID19. Informant Researchers were 8 people who were interviewed, consisting of Medical and Nonmedical. Research techniques in the form of the Preparation Phase, the Implementation Phase and Aids.

\section{RESULTS AND DISCUSSION \\ Human Resources Policy RSU Royal Prima In Terms of the Use of APD During the Pandemic.}

Based on the above interview human resources using APD is a Doctor, nurse emergency room, cleaning service, lab analyst also vice diektur medical services. Based on the interviews, it can be seen that the process of the protocol employed health human resources in the work face of this pandemic there is a corresponding sop there is not in accordance with sops established, such as APD indeed they use and wear with the procedures of each, not to take off recklessly When to wear when opened they follow the Directives in a mandatory right. Based on the results of Observations in the RSU Royal Prima, observed from work each all human resources have been using full APD in accordance with the SOP, ranging from gloves, masks, hazmat, head cover, and more.

The results of this Study in Accordance with the Standard Operating Procedures for the Handling of the Corona Virus diseases 2019 (COVID-19) the Department of Health of the Province of DKI Jakarta 2020 About the Use of APD is complete and the Process of its Use (DINKES DKI 2020).

The results of this Study in accordance with the Guidelines for the Fast Handling of Medical and Public Health COVID-19 in Indonesia About the Use of APD to the medical Team and the Manner of its Use (the Handling of the COVID19,2020).

The results of this Study in Accordance with the Guidelines of the World Health Organization a Model 

COVID-19.

hospital for COVID-19 patient management in the use of APD (WHO 2020).

\section{Human Resources Policy RSU Royal Prima In Terms of Maintaining Distance During the Pandemic.}

Based on the above interview human resources maintain a distance is All the human resources Doctor, nurse emergency room, cleaning service, lab analyst also vice diektur medical services, ranging from communication skills, rest and do the job. Based on the interviews, it can be seen that the process of protocol health is to maintain a distance of use of human resources in the work to face this pandemic from the observation of the Process in accordance with the imposed field that is at least maintain a distance of 1 meter to 2 meters, but not all hr can't do it like Nurse emergency room, doctors and analysts, traditional food with a Cleaning service of process in the work already different with the other health professionals they are more often face-to-face with the patient and hr itself. Based on the results of Observations in the RSU Royal Prima, observed from work each Keep a distance it looks still less than 1 meter.

The results of this Study in accordance with the World Health Organization a Model hospital for COVID19 patient management in maintaining a distance, who delivered the keep your distance as far as 2 meters wherever and whenever (WHO 2020).

The results of this Study in Accordance with the Theory Guidance for Corona Virus disease 2019: Prevention, control, Diagnosis and Management about how to keep a distance of 1 to 2 meters (Guidance COVID-19, 2020).

The results of this Study in Accordance with the Journal Nur Sholikah Princess Suni namely the Theory of Preparedness Indonesia to deal with the Potential Spread of Corona Virus Disease in terms of doing the keep your distance as far as 1 meter (Nur, 2020).

\section{Human Resources policy RSU Royal Prima in terms of doing Rapid Test.}

Based on the above interview human resources that perform the Rapid Test is Not all, after checking the Data that is there just Doctors and nurses. Based on the results of Observations in the RSU Royal Prima, observed from the place of work of each of them who do not get the right rapid test is to get the policy other Protocols such as Medicine supplement, nutritious food, and other. The policy process Rapid Test, human resources RSU Royal Prima not everything can be done Rapid test, they will do a Rapid test with human resources have a complaint, or with the human resources contact with the patient covid, although the Policy of the Rapid test in RSU Royal Prima issued, it only applies to certain provisions, the Boss will not do a Rapid test to all human resources, They will do Scale.

The results of this Study in Accordance with the Journal Nur Sholikah Princess Suni namely the Theory of Preparedness Indonesia to deal with the Potential Spread of Corona Virus Disease in terms of doing the keep your distance as far as 1 meter (Nur, 2020).

The results of this Study in accordance with the Guidelines for the Fast Handling of Medical and Public Health COVID-19 in Indonesia About Doing a screening scale to the medical Team on duty to serve patients Covid19 (Handling COVID-19, 2020).

The results of this Study in Accordance with the Guidelines of the World Health Organization a Model hospital for COVID-19 patient management in the Conduct of Rapid Test (WHO 2020).

\section{CONCLUSIONS AND RECOMMENDATIONS Conclusion}

Research and discussion that has been diuraikaan provide the Following conclusions:

1. Based on Human Resource Policy RSU Royal Prima in terms of the Use of APD when the pandemic was already in 
accordance with the Protocol recommended Health by the government or the WHO.

2. Based on Human Resource Policy RSU Royal Prima in terms of Maintaining Distance during the pandemic in accordance with the Protocol recommended Health by the WHO that Keep a Distance of 1 to 2 meters.

3. Based on Human Resource Policy RSU Royal Prima in terms of Doing Rapid test, there are 6 cases of Human Resource Positive COVID.

\section{Recommendations}

Based on the results of the conclusions of the study it can be stated the following suggestions:

1. Suggestions for Party RSU Royal Prima so Need to Reorganize the Appeal is serious to the Whole of Human Resources, especially The Medical Personnel in Order to really discipline in the underwent a Protocol of health So that it can abolish the Case of Positive Covid on Human Resources in RSU Royal Prima.

2. Need to Increase the update SOP in case of Human Resources terkomfirmasi Positive Covid, Pembahruan was issued back in when evaluating and already know his results.

3. In a Pandemic the whole of Human Resources, especially the frontline that medical Personnel are already struggling to sacrifice her soul, for it is expected that the Hospital can provide Motivation in the work and Appreciation.

Acknowledgement: None

\section{Conflict of Interest: None}

\section{Source of Funding: None}

\section{REFERENCES}

1. Argenti PA. Crisis communication: lessons from 9/11. Harvard Business Re-view. December 2002. https://hbr.org/2002/12/crisis- communication-les-sons-from-911.com.

Accessed April 2, 2020.

2. Argenti PA. Communicating through the coronavirus crisis. Harvard Business Review. March 2020. https://hbr.org/2020/03/communicatingthrough-the-coronavirus-crisis. Accessed April 2, 2020.

3. CapitalBio,Technology. Solution for the detection of pathogens of infection disease www.capitalbiotech.com/territory.

html?id=158 (article in chinese, accessed : march 11 th 2020).

4. DPRI,2009 undang-undang Republik Indonesia Nomor 44 tahun 2009 tentang Rumah sakit, Jakarta : Depkes RI.

5. Faastino Cardoso gomes,1995, managemen Sdm, Yogyakarta : Andy off set.

6. Guidance for corona virus deasease 2019: Prevention, Control.Diangnosis and management.

http://ww.pmph.com/.Copyright 2020 by people's medical publishing house. Allright reserved.

7. Herlambang.2018. Manajemen pelayanan Rumah sakit, Gosyen Publishing.

8. Kementrian kesehatan Republik Indonesia. 2003, keputusan mentri kesehatan Republik Indonesia nomor 560/menkes/IV/2003, Jakarta : Departemen kesehatan RI.

9. Kementrian kesehatan Republik Indonesia, 2010 peraturan kemenkes nomor 340/ menkes / PER/III/2010 tentang klasifikasi Rumah sakit, Jakarta : Departemen Kesehatan RI.

10. Kementrian kesehatan Republik Indonesia.2014,peraturan mentri kesehatan republic Indonesia Nomor 56 tahun 2014 tentang klasifikasi dan perizinan rumah sakit, Jakarta, Departemen kesehatan RI.

11. Kabat-Zinn J (1990). Full catastrophe living : Using the wisdom of your body and mind to face stress, pain, and illness. Dell Publishing, New York.

12. Manjas, 2017. Analisis Pengolahan logistic farmasi Rumah Sakit Islam Ibnu CIna padang tahun 2016 Tesis : Universitas Andalas padang.

13. Perhimpunan dokter paru Indonesia (PDPI 2020). Panduan Praktik klinis : Pneumonia 2019_nCoV.PDPI Jakarta.

14. Standar ILO dan COVID_19 di dunia kerja, ketentuan utama standar ketenagakerjaan internasional yang relevan dengan Wabah COVID_19 yang terus berkembang- 
http://www.ilo.org/global/Standards/WCMS 739937/Lang-en/index.htm

15. Tsai TC, Jacobson BH, Jha AK. American Hospital Capacity and ProjectedNeed for COVID-19. Health Affairs. March 17, 2020. https://www.healthaffairs.org/do/10.1377/hblog20200317.45791 0/full/. Accessed April 1, 2020.

16. WHO (2019) Mental Health During Covid19 Pandemic. Diakses pada tanggal 28 April 2020.

17. WHO (2020).Who Director-general's remaks at the media briefing on 2019-Covid on 11 February 2020 Cited Feb 13 rd 2020 Availible on

https://www.who.int/dg/speeches/detail/who -director-general-remaks-atthe-mediabriefing-on-2019-nCov-on-11-february2020. (Feb 12 th 2020).

18. WHO, 2020b WHO (Who Health Organisation) Laboratory testing for 2019 novel coronavirus (2019-nCoV) in suspected human cases. Interimguidance.2020. https//www.who.int/publicationsdetail/laboratory-testing-for-2019-novelcoronavirus-in-suspected-human-cases20200117, 2020b (accessed 15May 2020) yan W.Coronavirus testing goes in seattle, new York times, march 13-2020https://www.nytimes.com/2020/03/13/us/ Coronavirus-test- ing -drive throughtseattle. Html.Accessed April 2,2020.

How to cite this article: Afifa S, Girsang E, Nasution SW et.al. Analysis of the human resources policies RSU royal prima in the face of the pandemic of COVID-19. International Journal of Research and Review. 2021; 8(10): 282-288. DOI: https://doi.org/10.52403/ijrr. 20211038 